\title{
Pengaruh Edukasi AViRSex (Aid Video for Reproduction and Sexuality) terhadap Efikasi Diri Remaja Terkait Kesehatan Seksual dan Reproduksi di Kecamatan Ngemplak
}

\section{The Effect of AViRSex (Aid Video for Reproduction and Sexuality) Education Toward Adolescent's Sexual and Reproduction Health Self-Efficacy in Ngemplak District}

\author{
Etika Ratnasari ${ }^{1}$, Sri Hartini ${ }^{2 *}$, Widya Wasityastuti ${ }^{3}$ \\ ${ }^{1}$ Program Studi Ilmu Keperawatan, Fakultas Kedokteran, Kesehatan Masyarakat, dan \\ Keperawatan, Universitas Gadjah Mada \\ ${ }^{2}$ Departemen Keperawatan Anak dan Maternitas, Fakultas Kedokteran, Kesehatan \\ Masyarakat, dan Keperawatan, Universitas Gadjah Mada \\ ${ }^{3}$ Departemen Fisiologi, Fakultas Kedokteran, Kesehatan Masyarakat, dan Keperawatan, \\ Universitas Gadjah Mada
}

\begin{abstract}
Background: Self-efficacy is the ability to organize or carry out an action in achieving goals. Adolescence is a vulnerable period, since in this phase adolescents are in the genital phase and their sexual urge reaches its peak. Sexual and reproductive health self-efficacy is a person's belief in making decisions regarding his or her sexuality. Education plays important role in adolescents regarding their decision regarding sexual and reproductive health. Therefore, it is necessary to conduct research on the effect of AViRSex Education toward adolescent's sexual and reproduction health self-efficacy.

Objective: To find out the effect of AViRSex (Aid Video for Reproduction and Sexuality) Education toward adolescent's sexual and reproduction health self-efficacy.

Methods: This was quantitative research with quasi-experiment design which was conducted in November-Desember 2019 and took 122 students from SMP N 1 Ngemplak and SMP N 2 Ngemplak Sleman as research subjects. This research used the adolescent sexual and reproduction health selfefficacy questionnaire with validity score 0,97 and reliability score 0,74 . Data was analyzed using Paired t-test, Mann-Whitney, Pearson Product Moment, and Eta Test.

Result: There was a significant change in the pretest and post-test score of the intervention group $(\mathrm{p}=$ 0,008 ) while there was not any significant change in the pretest and post-test score of the control group $(p=0,367)$. There was not any significant difference between the pretest and post-test score of the control and intervention groups $(p=0,067)$. There was no relationship between self-efficacy with age $(r=$ $-0,039)$ and sexual reproductive health experiences $\left(F_{\text {count }}=2,062\right)$. There was a relationship between sex with self-efficacy $\left(F_{\text {count }}=6,28\right)$.

Conclusion: AViRSex Education could increase sexual and reproduction health self-efficacy score on 12-14 years old adolescent.
\end{abstract}

Keywords: adolescent, self-efficacy, sexual and reproduction health

\section{ABSTRAK}

Latar belakang: Efikasi diri merupakan kemampuan untuk mengatur atau melaksanakan suatu tindakan dalam mencapai tujuan. Masa remaja merupakan masa rentan, dimana remaja berada fase genital dan dorongan seksual yang mencapai fase puncak. Efikasi diri kesehatan seksual dan reproduksi merupakan keyakinan seseorang dalam memutuskan terkait dengan seksualitasnya. Edukasi berperan penting dalam membuat keputusan terkait kesehatan seksual dan reproduksinya. Oleh karena itu, perlu dilakukan penelitian mengenai pengaruh Edukasi AViRSex terhadap efikasi diri terkait kesehatan seksual dan reproduksi pada remaja.

Tujuan: Untuk mengetahui pengaruh Edukasi AVirSex (Aid Video for Reproduction and Sexuality) terhadap efikasi diri terkait kesehatan seksual dan reproduksi pada remaja. 
Metode: Penelitian ini merupakan penelitian kuantitatif dengan rancangan quasi-experimental. Penelitian dilaksanakan pada November - Desember 2019 dengan jumlah subjek sebanyak 122 siswa dari SMPN 1 dan SMPN 2 Ngemplak, Sleman. Instrumen yang digunakan adalah kuesioner efikasi diri kesehatan seksual dan reproduksi, dengan hasil validitas 0,97 dan reliabilitas 0,74 . Analisis data yang digunakan yaitu Paired t-test, Mann-Whitney, Uji Pearson, dan Uji Eta.

Hasil: Analisis data menunjukan adanya perubahan signifikan pada skor pre-test dan post-test kelompok intervensi $(p=0,008)$ dan tidak ada perubahan signifikan pada skor pre-test dan post-test kelompok kontrol $(p=0,367)$. Tidak ada perbedaan signifikan selisih skor efikasi diri pre-test dan posttest kelompok kontrol dan intervensi $(p=0,067)$. Tidak ada hubungan antara efikasi diri dengan usia $(r=$ $-0,039)$ dan pengalaman kesehatan seksual reproduksi $\left(F_{\text {hitung }}=2,062\right)$. Ada hubungan jenis kelamin dengan efikasi diri $\left(F_{\text {hitung }}=6,28\right)$.

Kesimpulan: AViRSex dapat meningkatkan skor efikasi diri kesehatan seksual dan reproduksi pada remaja usia $12-14$ tahun.

Kata Kunci: efikasi diri, kesehatan seksual dan reproduksi, remaja

\section{PENDAHULUAN}

Remaja merupakan seseorang yang berusia sekitar $10-19$ tahun. ${ }^{1}$ Populasi remaja di dunia sekitar $16 \%$ dari keseluruhan populasi. ${ }^{2}$ Populasi remaja di Indonesia sekitar $17 \%$ dari total populasi. ${ }^{3}$ Populasi remaja di Daerah Istimewa Yogyakarta sekitar $15 \%$ dari total penduduk. ${ }^{4}$ Kabupaten Sleman sebagai salah satu wilayah dengan penduduk terbanyak di Daerah Istimewa Yogyakarta, persentase jumlah remaja sebesar 13\% dari total jumlah penduduk. $^{5}$

Masa remaja adalah masa yang sangat rentan, karena pada masa ini terjadi perkembangan dan pertumbuhan yang progresif. ${ }^{6}$ Pada fase ini, remaja mengalami perkembangan psikoseksual pada fase genital. Dorongan seksual remaja mencapai fase puncak dan aktivitas sosial remaja yang lebih banyak di luar ruangan, terjadi pada fase ini. ${ }^{7}$ Pada usia remaja awal, akan terjadi perubahan pubertas yang signifikan dan akan menambah kesan maturitas pada remaja. Hal ini dimulai dari usia 12 tahun pada laki-laki dan usia 11 tahun pada perempuan. ${ }^{6}$

Kesehatan seksual dan reproduksi menjadi hal penting bagi remaja, menurut Kemenkes. ${ }^{8}$ Saat ini remaja berusia <15 tahun sudah mulai berpacaran. Pada usia ini, remaja belum memiliki soft skill yang baik sehingga dikhawatirkan mengarah pada seks bebas. Menurut Bandura, efikasi diri merupakan penilaian subjektif individu terhadap kemampuan untuk mengatur atau melaksanakan suatu tindakan dalam mencapai tujuan. ${ }^{9}$ Efikasi diri berhubungan dengan motivasi pada diri seseorang. Pada usia anak dan remaja, efikasi diri yang positif dibentuk bukan hanya sekadar motivasi secara verbal, akan tetapi perlu adanya implikasi. ${ }^{10}$

Pada usia remaja, efikasi diri terkait kesehatan seksual dan reproduksi tergolong rendah. ${ }^{11}$ Efikasi diri yang rendah akan memengaruhi perilaku remaja dalam kesehatan seksual dan reproduksi yang akan mengarah pada hal-hal negatif. ${ }^{12}$ Efikasi diri terhadap perilaku berisiko sebagai keyakinan bahwa seseorang mampu menghindari perilaku berisiko yang mempunyai pengaruh buruk pada kesehatan reproduksi. ${ }^{13}$ Efikasi diri berkontribusi sebesar $9,1 \%$ sebagai 
salah satu faktor yang memengaruhi perilaku berisiko pada remaja terkait kesehatan seksual dan reproduksi. ${ }^{13}$ Apabila efikasi diri individu semakin tinggi, maka dapat mengurangi perilaku seksual berisiko. ${ }^{14}$ Efikasi diri juga berhubungan berhubungan positif dengan fungsi seksual wanita, sehingga efikasi diri yang baik meningkatkan fungsi seksual yang baik pada wanita. ${ }^{15}$

Berdasarkan studi pendahuluan yang dilakukan di SMPN 1 dan SMPN 2 Ngemplak, 4 dari 5 siswa memiliki efikasi diri terhadap kesehatan seksual dan reproduksi yang tergolong rendah. $\mathrm{Hal}$ ini didukung dengan pendapat siswa mengenai sulit dalam menjaga kesehatan seksual dan reproduksi. Selain itu mereka mengatakan masih ragu dalam menjaga kesehatan seksual dan reproduksi dengan benar.

Pendidikan menjadi salah satu faktor yang memengaruhi kesehatan dan perkembangan seksual dan reproduksi ke depannya. ${ }^{6}$ Di Indonesia, sudah ada program pemerintah mengenai kesehatan seksual dan reproduksi. Salah satunya adanya fasilitas buku pedoman pelaksanaan Komunikasi Informasi Edukasi (KIE) tentang Kesehatan Seksual dan Reproduksi. ${ }^{16}$ Di Propinsi DI Yogyakarta, program yang dilaksanakan untuk mendukung pemenuhan hak kesehatan seksual dan reproduksi bagi remaja dituangkan melalui suatu modul yang ditujukan untuk siswa SMP kelas 7 dan 8. Modul ini disusun oleh PKBI DIY bersama para guru pengampu. Akan tetapi, berbagai hambatan masih banyak dihadapi, di antaranya, terbatasnya jam pelajaran, keterbatasan pengajar, pendanaan, metode, dan materi, serta kebijakan pendidikan pemerintah. ${ }^{17}$

Penelitian ini mengambil lokasi sampel dan wawancara di SMPN 1 dan 2 Ngemplak, salah satu sekolah menengah di wilayah Sleman (Kecamatan Ngemplak). Dari 15 siswa, sebanyak 11 siswa pernah mendapat pendidikan seksual reproduksi dan 6 siswa memahami materi yang disampaikan, sedangkan 5 siswa tidak paham mengenai materi yang disampaikan. Mereka menilai penyampaian yang kurang menarik karena hanya disajikan melalui power point dan oral presentation. Oleh karena itu, pengembangan yang dilakukan pada penelitian ini yaitu dengan audio visual berupa AViRSex dengan tujuan meningkatkan pengetahuan yang akan memengaruhi efikasi diri remaja. Menurut teori Edgar Dale, bahwa informasi yang disampaikan melalui audio visual akan diserap sebanyak $30 \%$, sedangkan jika hanya mendengarkan (audio), akan diserap sebesar $20 \%$ saja. ${ }^{18}$ Pengetahuan atau pemahaman yang baik akan memengaruhi efikasi diri dalam mengambil keputusan terhadap kebersihan seksual dan reproduksinya. Maka peneliti tertarik untuk memberikan intervensi pendidikan kesehatan seksual dan reproduksi dengan AViRSex, untuk mengetahui apakah ada pengaruh media audio visual terhadap efikasi diri remaja di Kecamatan Ngemplak.

\section{METODE PENELITIAN}

Penelitian ini merupakan penelitian kuantitatif dengan rancangan quasi-experimental yang dilakukan dua kali pengukuran yaitu pretest dan post-test. Penelitian dilakukan dengan 
melakukan pengukuran pada kelompok kontrol dan kelompok intervensi. Pengambilan data dilakukan setelah mendapat izin kelayakan etik dari komisi etik FK-KMK dengan nomor KE/FK/0831/EC/2019.

Tempat penelitian berada di SMPN 1 Ngemplak sebagai kelompok kontrol dengan jumlah sampel 61 siswa dan SMPN 2 Ngemplak sebagai kelompok intervensi dengan jumlah sampel 61 siswa. Teknik pengumpulan sampel dengan consecutive sampling yaitu dengan memenuhi jumlah sampel sesuai dengan kriteria inklusi dan eksklusi.

Instrumen yang digunakan adalah rancangan dari peneliti utama yaitu Sri Hartini S.Kep., Ns., M.Kes., Ph.D yang telah dilakukan uji validitas konten dan uji validitas konstruk sebelum digunakan. Hasil uji validitas konten oleh tiga pakar memiliki nilai CVI di antara -1 dan $+1(0,97)$. Hasil uji validitas konstruk terhadap 96 siswa di SMPN 1 Depok menunjukkan hasil bahwa seluruh item pertanyaan bernilai signifikan $(p$ value $<0,05)$ dan $r_{\text {hitung }}>r_{\text {tabel }}$, sehingga dapat disimpulkan bahwa seluruh item valid.

Pretest dilaksanakan sebelum melakukan intervensi pada kedua kelompok. Intervensi pada kelompok kasus diberikan 7 menit 31 detik sebanyak satu kali dengan metode menayangkan video (AViRSex) pada kelompok kasus. Intervensi pada kelompok kontrol adalah pendidikan reproduksi biasa yang diterima dari sekolah. Edukasi AViRSex berisi penjelasan mengenai anatomi dan fungsi organ reproduksi, toileting dan kebersihan, kesopanan dan pergaulan, serta rasa malu. Setelah diberikan intervensi, maka dilakukan posttest 3 minggu setelah pemberian intervensi.

Paired t-test digunakan untuk menguji perbedaan skor pada kelompok kasus dan kontrol sebelum dan setelah intervensi. Mann-Whitney Test digunakan untuk membandingkan selisih skor antara kedua kelompok. Pearson Product Moment dan Uji Eta digunakan untuk mengetahui hubungan variabel luar (usia, jenis kelamin, dan pengalaman) dengan efikasi diri.

Sebelum dilakukan penelitian, responden telah menyetujui dan diizinkan oleh orang tua untuk mengikuti penelitian ini. Hal ini ditunjukkan dengan menandatangani lembar persetujuan yang telah diberikan oleh tim peneliti, disertai penjelasan terkait penelitian yang akan dilakukan.

\section{HASIL}

Data karakteristik responden ditampilkan pada Tabel 1. Dari Tabel 1, dapat diketahui bahwa tidak terdapat perbedaan signifikan pada variabel usia dan jenis kelamin ( $p$ value $>0,05)$. Sementara itu terdapat perbedaan signifikan pada variabel pengalaman mendapat pendidikan kesehatan seksual dan reproduksi sebelumnya ( $p$ value $<0,05$ ). Karakteristik responden terdiri dari usia, jenis kelamin, dan pengalaman pendidikan kesehatan seksual dan reproduksi sebelumnya. Rata-rata usia responden pada penelitian ini 12,52 tahun (kelompok kontrol) dan 12,53 (kelompok intervensi). Penyebaran usia responden menunjukkan data yang homogen dan hasil tidak signifikan ( $p$ value $>0,05$ ). Jenis kelamin 
pada kelompok kontrol dan intervensi diperoleh persentase responden perempuan lebih banyak daripada responden laki-laki.

Tabel 1. Data demografi responden $(n=122)$

\begin{tabular}{|c|c|c|c|c|c|c|c|}
\hline \multirow{3}{*}{$\begin{array}{l}\text { Karakteristik } \\
\text { Responden }\end{array}$} & \multicolumn{6}{|c|}{ Kelompok } & \multirow[t]{3}{*}{ p value } \\
\hline & \multicolumn{3}{|c|}{ Kontrol } & \multicolumn{3}{|c|}{ Intervensi } & \\
\hline & f & $\%$ & Mean \pm SD & f & $\%$ & Mean \pm SD & \\
\hline Usia (tahun) & & & $12,52 \pm 0,47$ & & & $12,53 \pm 0,62$ & $0,968^{a}$ \\
\hline Jenis kelamin & & & & & & & $0,715^{\mathrm{b}}$ \\
\hline Laki- laki & 26 & 42,6 & & 28 & 45,9 & & \\
\hline Perempuan & 35 & 57,4 & & 33 & 54,1 & & \\
\hline Pengalaman Penkespro & & & & & & & $0,000^{\mathrm{b} *}$ \\
\hline Pernah & 58 & 95,1 & & 40 & 65,6 & & \\
\hline Belum pernah & 3 & 4,9 & & 21 & 34,4 & & \\
\hline
\end{tabular}

Gambaran efikasi diri kesehatan seksual dan reproduksi responden ditampilkan pada Tabel 2. Dari Tabel 2 dapat dilihat bahwa, gambaran efikasi diri kesehatan seksual dan reproduksi pada remaja berada pada kategori sedang. Pada kelompok intervensi terjadi penurunan kategori gambaran efikasi diri dari tinggi ke sedang atau rendah. Rata-rata frekuensi skor tertinggi pada setiap item mengalami peningkatan sebelum dan setelah diberikan intervensi. Data pretest menunjukkan skor tertinggi pada kelompok kontrol lebih tinggi dari kelompok intervensi.

Tabel 2. Gambaran efikasi diri kesehatan seksual dan reproduksi $(n=122)$

\begin{tabular}{lrrrrrrrr}
\hline \multirow{2}{*}{ Kategori } & \multicolumn{3}{c}{ Kontrol } & \multicolumn{4}{c}{ Intervensi } \\
\cline { 2 - 9 } & \multicolumn{2}{c}{ Pretest } & \multicolumn{1}{c}{ Post-test } & Pretest & Post-test \\
\cline { 2 - 9 } & $\mathbf{f}$ & $\%$ & $\mathbf{f}$ & $\%$ & $\mathbf{f}$ & $\%$ & f & $\%$ \\
\hline Tinggi & 11 & 13,1 & 14 & 23,0 & 13 & 13,1 & 11 & 18,0 \\
Sedang & 42 & 68,9 & 41 & 67,2 & 40 & 65,6 & 39 & 63,9 \\
Rendah & 8 & 18,0 & 6 & 9,8 & 8 & 13,1 & 11 & 18,0 \\
\hline
\end{tabular}

Hubungan efikasi diri responden dengan variabel luar ditampilkan pada Tabel 3. Berdasarkan Tabel 3, dapat dilihat bahwa usia memiliki $p$ value $>0,05$ sehingga dapat disimpulkan bahwa usia tidak berhubungan dengan efikasi diri. Jenis kelamin memiliki $F_{\text {hitung }}>F_{\text {tabel }}$ dengan $F_{\text {tabel }}$ bernilai 3,92 sehingga dapat disimpulkan bahwa terdapat hubungan antara jenis kelamin dengan efikasi diri. Sementara $F_{\text {hitung }}$ pada Penkespro $<F_{\text {tabel }}$ sehingga dapat disimpulkan bahwa tidak ada hubungan antara efikasi diri dengan pengalaman mendapat pendidikan kesehatan seksual dan reproduksi sebelumnya.

Tabel 3. Hubungan efikasi diri dengan variabel luar $(n=122)$

\begin{tabular}{ll}
\hline & Pretest Skor Efikasi \\
\hline Usia & $\mathrm{r}=-0,039$ \\
& $\mathrm{p}=0,668^{\mathrm{a}}$ \\
& $\mathrm{n}=122$ \\
\hline Jenis kelamin & Uji Eta $=0,232$ \\
& $\mathrm{f}_{\text {hitung }}=6,82^{\mathrm{b}^{*}}$ \\
\hline Pengalaman Penkespro & $\mathrm{Uji}_{\mathrm{ji}} \mathrm{Eta}=0,126$ \\
& $\mathrm{f}_{\text {hitung }}=2,062^{\mathrm{b}}$ \\
\hline
\end{tabular}

aUji Pearson Rank, bUji Eta, *korelasi bermakna $F_{\text {hitung }}>F_{\text {tabel }}$ 
Hasil uji beda skor efikasi diri pada kedua kelompok ditampilkan pada Tabel 4. Berdasarkan Tabel 4, dapat diketahui bahwa terdapat perbedaan signifikan pada kelompok intervensi $(p$ value $<0,05)$ dan tidak ada perbedaan signifikan pada kelompok kontrol ( $p$ value $>0,05)$. Kelompok kontrol memiliki skor pretest yang lebih tinggi dari kelompok intervensi. Sementara skor post-test juga menunjukan bahwa kelompok kontrol memiliki skor lebih tinggi dari kelompok intervensi. Uji beda dilakukan untuk mengetahui peningkatan efikasi diri setelah diberikan intervensi. Sebelumnya telah dilakukan uji terhadap skor pretest untuk mengetahui baseline data. Hasil analisis menunjukkan bahwa skor pretest kedua kelompok mempunyai perbedaan signifikan. Kelompok kontrol memiliki skor pretest efikasi diri yang lebih tinggi dibanding kelompok intervensi. Uji beda menunjukkan hasil bahwa secara statistik pada kelompok kontrol tidak menunjukkan perubahan secara signifikan, sedangkan pada kelompok intervensi menunjukkan perubahan yang signifikan.

Tabel 4. Peningkatan rerata skor efikasi diri seksual kelompok kontrol dan intervensi $(n=122)$

\begin{tabular}{|c|c|c|c|c|}
\hline \multirow{2}{*}{ Kelompok } & \multicolumn{2}{|c|}{ Mean \pm SD } & \multirow{2}{*}{$\Delta$ Mean \pm SD } & \multirow{2}{*}{$p$ value } \\
\hline & Pretest & Post-test & & \\
\hline $\begin{array}{l}\text { Kontrol } \\
n=(61)\end{array}$ & $41,18 \pm 5,26$ & $41,67 \pm 5,92$ & $0,49 \pm 4,22$ & 0,367 \\
\hline $\begin{array}{l}\text { Intervensi } \\
\mathrm{n}=(61)\end{array}$ & $38,59 \pm 6,94$ & $41,21 \pm 5,98$ & $1,62 \pm 7,40$ & $0,008^{*}$ \\
\hline
\end{tabular}

*Signifikan $p$ value $<0,05$

Tabel 5. Selisih rerata efikasi diri kesehatan seksual dan reproduksi $(n=122)$

\begin{tabular}{lccc}
\hline \multicolumn{1}{c}{ Kelompok } & $\begin{array}{c}\text { Median } \\
\text { (Minimum - Maximum) }\end{array}$ & Mean Rank & p value \\
\hline Kontrol & $0,000(-10-11)$ & 55,65 & 0,067 \\
\hline Intervensi & $1,000(-14-21)$ & 67,35 & \\
\hline
\end{tabular}

Uji beda selisih skor efikasi diri antara dua kelompok ditamilkan pada Tabel 5. Berdasarkan Tabel 5, dapat dilihat bahwa setelah dilakukan uji beda tidak terdapat perbedaan signifikan antara selisih skor efikasi diri kesehatan seksual dan reproduksi pada kelompok kontrol maupun kelompok intervensi. Kelompok intervensi memiliki nilai median dan nilai maksimum lebih tinggi dari kelompok kontrol, akan tetapi memiliki nilai minimum yang lebih rendah dari kelompok kontrol. Hasil uji beda selisih peningkatan skor efikasi diri kesehatan seksual dan reproduksi, secara statistik menunjukkan hasil yang tidak signifikan. Nilai median kelompok kontrol lebih rendah dari kelompok intervensi. Nilai minimum dan maksimum selisih skor efikasi diri pada kelompok intervensi memiliki skor lebih tinggi daripada kelompok kontrol. Hasil ini dipengaruhi oleh baseline data bahwa skor pretest kelompok kontrol mempunyai skor awal yang lebih tinggi dari kelompok intervensi. Baseline data yang berbeda secara signifikan memengaruhi peningkatan skor efikasi pada kelompok intervensi, sehingga setelah dianalisis, selisih skor menunjukkan tidak ada perbedaan yang signifikan antar kedua kelompok. 


\section{PEMBAHASAN}

Rata rata usia responden pada penelitian ini adalah 12,5 tahun pada kedua kelompok. Hasil penelitian ini sesuai dengan target penelitian yang dilakukan oleh Robinson ${ }^{19}$ dengan subjek remaja usia 10-19 tahun. Informasi mengenai kesehatan seksual dan reproduksi penting diberikan pada usia remaja awal yaitu usia 10-14 tahun. ${ }^{20}$

Penelitian yang dilakukan oleh Muflih et al. ${ }^{21}$ mengenai konseling SMS Gateway terhadap efikasi diri remaja mendapatkan 450 responden dengan persentase $92,2 \%$ berjenis kelamin perempuan dengan hasil efikasi diri responden perempuan lebih rendah daripada responden laki-laki. Efikasi diri kesehatan seksual dan reproduksi pada perempuan berpengaruh terhadap fungsi seksualnya. ${ }^{15}$ Pada kelompok kontrol dan intervensi memiliki perbedaan yang signifikan mengenai pengalaman mendapat pendidikan kesehatan seksual dan reproduksi sebelumnya. Pada kedua kelompok, sebagian besar responden telah mendapat pendidikan kesehatan seksual dan reproduksi sebelumnya. Hasil ini berbeda dengan penelitian yang dilakukan oleh Alavi-Arjaz et al..22 mempunyai target responden lebih banyak yang belum mendapat pengalaman pendidikan sebelumnya.

Hasil penelitian yang sama pada penelitian Alavi-Arjaz et al. ${ }^{22}$ bahwa skor pretest kelompok kontrol memiliki skor lebih tinggi dari intervensi. Pemberian informasi melalui media audiovisual dapat meningkatkan efikasi diri. ${ }^{23}$ Informasi yang disampaikan menggunakan media audiovisual, akan mampu diserap sebesar $30 \% .^{18}$

Gambaran frekuensi efikasi diri dibedakan menjadi 3 kategori yaitu tinggi, sedang, dan rendah. Hasil penelitian ini menunjukkan bahwa kelompok kontrol dan intervensi mayoritas termasuk ke dalam kategori efikasi diri sedang. Pada kelompok intervensi, frekuensi kategori rendah bertambah setelah diberikan intervensi dan frekuensi kategori tinggi berkurang setelah diberikan intervensi. Penurunan frekuensi efikasi diri pada kelompok intervensi menunjukkan bahwa terdapat faktor yang memengaruhi. Efikasi diri rendah berpengaruh terhadap perilaku negatif remaja terhadap seksual dan reproduksi. ${ }^{12}$ Pada penelitian Atrian et al. ${ }^{15}$ menunjukkan bahwa efikasi diri yang rendah pada perempuan akan memengaruhi fungsi seksual yang buruk.

Pada usia ini juga merupakan puncak perkembangan remaja dalam mencapai identitas dirinya. ${ }^{6}$ Usia tidak berhubungan dengan efikasi diri $(r=-0,03)$. Hasil ini sesuai dengan penelitian Alavi-Arjas et al. ${ }^{22}$ yang menyatakan bahwa tidak ada hubungan antara efikasi diri dengan usia. Pada penelitian ini usia responden cukup homogen sehingga tidak dianalisis sesuai dengan tahapan usia. Hasil korelasi menunjukkan bahwa jenis kelamin mempunyai korelasi kuat dengan peningkatan skor efikasi diri.

Hasil penelitian ini menunjukkan rata-rata efikasi perempuan lebih tinggi daripada laki-laki. Pada perempuan mempunyai nilai efikasi sebesar 40,97 $\pm 6,19$ dan pada laki-laki sebesar $38,47 \pm 6,15$. Jenis kelamin mempunyai hubungan yang signifikan terhadap efikasi diri. Hasil yang sama dikemukakan oleh Muflih et al. ${ }^{21}$ bahwa jenis kelamin dapat memengaruhi efikasi 
diri pada remaja dalam mencegah perilaku seks bebas dan HIV/AIDS. Berbeda dengan penelitian Maria ${ }^{24}$ yang menyatakan bahwa tidak ada hubungan antara jenis kelamin dengan efikasi diri. Pengalaman kesehatan reproduksi sebelumnya juga tidak berhubungan dengan efikasi diri. ${ }^{24}$ Hasil uji korelasi menunjukkan bahwa tidak ada hubungan antara pengalaman pendidikan sebelumnya. Hasil yang sama dikemukakan pada penelitian Maria ${ }^{24}$ yang menyatakan bahwa tidak ada hubungan antara keterpaparan informasi dengan pengetahuan dan self-efficacy. Berbeda dengan teori Bandura yang menyatakan bahwa pemahaman efikasi diri berasal dari pengalaman yang telah diterima sebelumnya. ${ }^{6}$

Dapat disimpulkan bahwa terjadi peningkatan efikasi diri remaja tentang kesehatan seksual dan reproduksi pada kelompok intervensi. Hal ini sesuai dengan penelitian Alavi-Arjaz et al. ${ }^{22}$ yang menunjukkan bahwa ada peningkatan skor efikasi diri tentang kesehatan seksual dan reproduksi pada kelompok intervensi yaitu dengan pendidikan metode TBL (Team Based Learning). Penelitian lain yang mempunyai hasil sama yaitu Downs et al. ${ }^{23}$ yang menunjukkan bahwa efikasi diri meningkat dengan pemberian intervensi dengan video. Hasil yang berbeda pada penelitian Parmawati ${ }^{25}$ bahwa tidak terjadi peningkatan skor efikasi diri pada kelompok intervensi setelah diberikan edukasi kesehatan berbasis gender.

Pengaruh pendidikan kesehatan terhadap peningkatan skor efikasi diri remaja dapat dipengaruhi oleh beberapa hal di antaranya pemberian video dapat meningkatkan daya tarik responden terhadap materi yang disampaikan. Berdasarkan teori Edgar, informasi yang dapat diterima dari media audiovisual sebesar $30 \% .{ }^{18}$ Menurut penelitian Parmawati ${ }^{25}$ terdapat hubungan sedang antara skor pengetahuan dengan efikasi diri kesehatan seksual. Selain itu, durasi yang diberikan selama 7 menit 36 detik menjadi salah satu kelebihan dari media yang dipaparkan. Dari evaluasi yang diberikan kepada responden, sebanyak 92,6\% responden menyatakan bahwa durasi video AViRSex tidak terlalu panjang dan 64,7\% menyatakan lebih paham dengan materi yang disampaikan. Pada penelitian ini, domain yang paling kuat mengalami peningkatan pada domain sentuhan. Menurut Zimmermar, generalisasi salah satu dimensi efikasi diri yang berkaitan dengan keyakinan seseorang dalam melakukan suatu hal dalam cakupan luas. ${ }^{26}$ Dalam domain sentuhan berisi tentang keyakinan seseorang berdasarkan situasi yang bervariasi atau cakupan yang luas.

Hasil dari penelitian ini sesuai dengan penelitian Parmawati ${ }^{25}$ dan Oktaria $^{27}$ yang menunjukkan bahwa tidak ada perubahan secara signifikan setelah dibandingkan dengan kelompok kontrol. Hasil yang berbeda pada penelitian Castro et al. ${ }^{28}$ yang menunjukkan terdapat perbedaan signifikan peningkatan efikasi diri dengan Comprehensive Sex Education (CSE) terhadap kelompok kontrol.

Efikasi diri merupakan salah satu faktor yang memengaruhi perilaku seksual remaja. Remaja yang memiliki efikasi diri rendah berpeluang untuk melakukan perilaku seksual negatif dibanding dengan remaja yang memiliki efikasi diri tinggi. ${ }^{12}$ Perbedaan skor yang tidak 
signifikan antara efikasi diri seksual dan reproduksi pada penelitian ini menandakan bahwa ada faktor selain AViRSex yang memengaruhi peningkatan skor. Pendidikan kesehatan reproduksi yang dapat meningkatkan efikasi diri dapat dilakukan beberapa kali, hingga jangka waktu 6 bulan. ${ }^{23}$ Faktor lain yang memengaruhi efikasi diri yakni adanya diskusi tentang materi yang disampaikan. Diskusi merupakan bagian dari evaluasi terhadap materi yang bertujuan untuk meningkatkan motivasi pendengar terkait materi yang disampaikan. ${ }^{29}$ Pada penelitian ini, diskusi kurang berjalan dengan baik karena dalam satu ruangan tidak dipisah antara remaja laki-laki dan remaja perempuan, sehingga sesi diskusi tidak berjalan efektif. Selain itu, pengambilan data post-test dilakukan pada saat kegiatan siswa, sehingga konsentrasi terpecah ketika mengerjakan kuesioner. Pembentukan efikasi diri seharusnya disampaikan tidak hanya dalam satu kali waktu, bisa dilakukan follow up dalam kurun waktu 6 bulan. ${ }^{23}$

Menurut teori Bandura, kondisi fisiologis memengaruhi efikasi diri individu dalam menilai kemampuannya. Pada saat seseorang merasa tegang dan tertekan, maka akan melemahkan performa individu. Jika seseorang dalam kondisi fisiologis yang baik, maka akan meningkatkan kemampuan performa individu. ${ }^{26}$ Peneliti tidak mengukur kondisi fisiologi responden ketika dilakukan pretest dan post-test karena keterbatasan peneliti, sehingga tidak dapat dijelaskan pengaruh kondisi fisiologis responden terhadap efikasi diri terhadap kesehatan seksual dan reproduksi.

\section{KESIMPULAN DAN SARAN}

Remaja rata-rata memiliki gambaran efikasi diri sedang hingga baik, pada saat sebelum dan setelah dilakukan intervensi. Efikasi diri tidak berhubungan dengan usia dan pengalaman pendidikan keseharan reproduksi sebelumnya, namun berhubungan dengan jenis kelamin. Remaja perempuan ternyata mempunyai efikasi diri yang lebih tinggi dibanding remaja lakilaki. Edukasi AViRSex dapat meningkatkan skor efikasi diri pada remaja. Namun, setelah dibandingkan dengan pendidikan biasa, ternyata tidak terdapat perbedaan yang signifikan.

\section{UCAPAN TERIMA KASIH}

Penelitian ini merupakan proyek penelitian payung dengan dana hibah dari FK-KMK UGM. Penulis juga mengucapkan terima kasih kepada SMPN 1 Ngemplak dan SMPN 2 Ngemplak yang telah menjadi responden dalam penelitian dan membantu jalannya penelitian hingga akhir.

\section{DAFTAR PUSTAKA}

1. Stiritz S. Aasect at 50: Visions for Sexuality Education and Therapy (Aasect Symposium) 23rd Congress of The World Association for Sexual Health SY-09 Unmet Needs in Sexual Care (Essm Symposium) Konnie MCCAFFREE Widener University Center for Human Sexuality Stu. J Sex Med. 2017;14(5):e226. Diakses pada laman: http://dx.doi.org/10.1016/j.jsxm.2017.04.186.

2. WHO. Coming of Age: Adolescent Health. 2016 [dikutip 10 Juli 2019]. World Health Organization. Diakses pada laman: https://www.who.int/

3. Kemenkes. Data dan Informasi Profil Kesehatan Indonesia. Jakarta: Kementrian Kesehatan; 2017 
4. Dinas Kesehatan. Profil Kesehatan Daerah Istimewa Yogyakarta 2016. Dinas kesehatan DIY. Yogyakarta: Dinas Kesehatan DIY; 2017.

5. BPS Sleman. Banyaknya Penduduk Berdasarkan Kelompok Umur. 2017. Badan Pusat Statistik Sleman.

6. Potther G A , Perry. Fundamental Keperawatan. 7th. ed. Singapura: Elsevier Inc; 2010.

7. Potter G A, Perry . Basic Nursing Seventh Edition. 7th ed. Canada: Elsevier; 2011.

8. Kemenkes. Infodatin Pusat Data dan Informasi Kesehatan Reproduksi Remaja. 2015.

9. Zimmerman BJ. Adolescents Development of Personal Agency. In F. Pajares, Self-Efficacy Beliefs of Adolescents. Greenwich: Infromation Age Publishing; 2005.

10. Pajeres F. Self-Efficacy during Childhood and Adolescence. United Kingdom: Information Age Publishing; 2005.

11. Mustalia, Suryoputro A, Widjanarko B. Perilaku Seksual Remaja di Lingkungan Lokalisasi Kabupaten Sidoarjo. Jurnal Promosi Kesehatan Indonesia. 2016; 11 (01): 1- 15.

12. Murhadi T, Kurniawati E. The Effect of Self Efication Factors on Teenager. Journal of Healthcare Technology and Medicine. 2019; 5(2): 239-46.

13. Anggai A I. Hubungan antara Efikasi Diri dengan Perilaku Berisiko terhadap Kesehatan pada Remaja. Universitas Muhammadiyah Surakarta; 2015.

14. Winarni. Efikasi Diri dan Perilaku Seksual Pranikah Remaja SMA. GASTER. 2017; XV(2): 232-9.

15. Atrian MK, Dehnavi ZM, Kamali Z. The Relationship between Sexual Self-Efficacy and Sexual Function in Married Women. J midwifery Reprod Heal. 2018; 7(2): 1683-90.

16. Kemenkes. Bagi Para Remaja, Kenali Perubahan Fisik untuk Menghindari Masalah Seksual. Kementerian Kesehatan Republik Indonesia. 2018 [dikutip 20 Juni 2019]. Diakses pada laman: http://www.depkes.go.id/

17. PKBI DIY. Alasan Kenapa Pendidikan Kesehatan Seksual dan Reproduksi Penting. 2018. Perkumpulan Keluarga Berencana Indonesia. Yogyakarta: PKBI DIY

18. Nugroho. Menerapkan Teori Kerucut Pengalaman Edgals Dale dalam Diklat. Badan Pendidikan dan Pelatihan Keuangan Kementerian Keuangan. 2017 [dikutip 30 Juli 2019]. Diakses pada laman: www: https://bppk.kemenkeu.go.id/id/

19. Robinson JL, Narasimhan M, Amin A, Morse S, Beres K, Yeh PT, et al. Interventions to Address Unequal Gender and Power Relations and Improve Self-Efficacy and Empowerment for Sexual and Reproductive Health Decision-making for women living with HIV: A systematic review. Plos One; 12 (8) 2017: 1-19.

20. Nations U, Unicef F. Adolescence An Age of Opportunity. 2011.

21. Muflih M, Setiawan DI. Pengaruh Konseling Short Message Service (SMS) Gateway terhadap Self Efficacy Menghindari Seks Bebas dan HIV / AIDS Remaja The Effect of Counseling Short Message Service (SMS) Gateway on Self Efficacy to Avoid Free Sex and HIV/AIDS Adolescent. 5(April 2017): 1-9.

22. Alavi-Arjas F, Farnaz F, Mehrnaz Granmayeh HH. The Effect of Sexual and Reproductive Health Education on Knowledge and Self-Efficacy of School Counselors. J Adolesc Heal [Internet]. 2018;63(5):615-20. Tersedia pada: https://doi.org/10.1016/j.jadohealth.2018.05.031

23. Downs JS, Ashcraft AM, Murray PJ, Bruin B De, Mpa JE, Fischhoff B, et al. Study Video Intervention to Increase Perceived Self-Ef fi cacy for Condom Use in a Randomized Controlled Trial of Female Adolescents. Pediatr Adolesc Gynecol. 2018;xxx:291-8.

24. Maria Y. Pengaruh Pelatihan Promosi Kesehatan tentang Pencegahan HIV/AIDS terhadap Pengetahuan, Self Efficacy dan Keterampilan Mahasiswa Keperawatan Universitas Nusa Nipa di Maumere. Skripsi. 2017;1-122.

25. Parmawati I. Pengaruh Pendidikan Kesehatan Reproduksi Berbasis Kesetaraan Gender dalam Meningkatkan Pengetahuan, Sikap, dan Efikasi Diri Remaja Putri di Wilayah Kerja Puskesmas Temon 1 Kulon Progo Yogyakarta. Thesis. 2015;6.

26. Ghufron. Teori-Teori Psikologi. Yogyakarta: Ar-Ruzz media; 2012.

27. Oktarina J. Adln - Perpustakaan Universitas Airlangga. 2016;

28. Castro FD, Rojas-martı R, Uribe-zu P. Sexual and Reproductive Health Outcomes are Positively Associated with Comprehensive Sexual Education Exposure in Mexican Highschool Students. Plos One. $2018 ; 13$ (3):115.

29.Arsyad. Media Pembelajaran. Edisi Revisi. Jakarta: PT. Raja Grafido Persada; 2017. 1-243. 